\title{
Meritocracy of Bureaucracy in Indonesia
}

\author{
Fauzul Mubin and Ali Roziqin
}

\begin{abstract}
This paper explains how Merit System is implemented in Indonesian bureaucracy. Bureaucracy condition which is very complex and has many bureaucratic pathologies often leads to less optimal bureaucracy itself. Based on these problems and also the development and demands of society for the role of bureaucratic functions, Merit System is considered as a solute step to optimize the bureaucracy in achieving the goals of the state. In this paper, the authors used qualitative descriptive method, which data obtained from literature and observation studies. The result of this paper is that Indonesian bureaucracy has begun to implement the Merit System. This is known from the existence of various instruments such as legislation, authorized institutions, and the system of recruitment or auction of positions based on Merit System.
\end{abstract}

Index Terms-Merit system, bureaucracy, open recruitment

\section{INTRODUCTION}

Public administration in various occasions is often interpreted as a government bureaucracy. Many public administration scientists, including in Indonesia, imply that public administration is the bureaucracy itself. The history of bureaucracy in Indonesia has been going on for a long time. Starting from the period of kingdom / feudal or often called pangreh praja until the colonial period was called indlandsch bestuur [1]. Time by time, Indonesian bureauracy has change. State (power perspective), as a night watchman, becomes public servant (public services) with the concept of welfare state [2]. The impact is almost people will depend their life on the bureaucracy. Unfortunately, Indonesia's bureaucracy has undergone many bureaucratic pathologies, which later became bureaucratic officialdom [3].

\section{A. Background}

Bureaucracy in Indonesia is a driving force in realizing the goals of nation and state. This means that the bureaucracy has a big influence on the progress of a nation. However, the bureaucrats that are formed in Indonesia are mostly paradoxical and contradictory to the objectives of the bureaucratic concept itself. The concept of bureaucracy [4], [5], [6] is described; A fixed division of labor (horizontal differentiation) a hierarchy of authority-based positions (vertical differentiatiaon), written documents and general rules (standardization and formalization), and the use of expert.

Indonesia is part of welfare state. The concept of the

Manuscript received May 30, 2018; revised August 27, 2018.

Fauzul Mubin is with Ministry of Law and Human Rights. He is also a student in Magister of Public Administration, Universitas Gadjah Mada, with sponsor Indonesia Endowment Fund for Education, Financial Ministry, Indonesia (e-mail: fauzulmubin2012@gmail.com).

Ali Roziqin is with Magister of Public Administration, University of Gadjah Mada, Indonesia (e-mail: ali_roziqin@ymail.com) welfare state requires the bureaucracy to be strong in running its role [7]. Bureaucracy in Indonesia plays an important role in the life of nation and state. Especially with the development of welfare state, it gives an opportunity to the state represented by government and bureaucracy to touch all aspects of community life [8].

To fulfill these fundamental bureaucratic roles and tasks, the bureaucracy must be able to be the answer to public problems. Not only serve, but also participatory and realize social justice. To achieve these objectives, bureaucrats must be superior, transformative (more than serving), professional, and have high integrity [9]. Social changes that occur either sooner or later require the bureaucracy to adapt to these changes, including providing public services to the society.

However, the high expectations to bureaucracy and public services are not in line with factual conditions. Bakhtiar [10] describes that the reality of today's bureaucracy is one that emphasizes on authority but lacks the support of professional apparatus, suitably competent in their own fields of function. The employment system has yet to be based on the merit system though the merit system has political consequences [11]. For instance, when the number and qualification of PNS are retired [12]. Implementing state bureaucracy cannot be separated from problems, which is the point of bureaucratic emphasis is accountability, control, equity, procedural regularity, efficiency, responsiveness and Fiscal integrity [13]. From this aspect, many experts have concluded that the performance of government in the reform era is still below the level that can be achieved by the government of the new order whose procedural nature is in contrast to the demands of good governance [14]. Furthermore, James Q. Wilson calls it a "bureaucracy problem" that is, in the sense that it is not in accordance with the means of prioritizing them [15]. These conditions are somewhat influenced by the capacity of human resources in the bureaucracy.

Since the old era order until the reform era, bureaucracy is famous for the practice of corruption, collusion, nepotism (KKN). State Civil Service resources are deemed incompetent to keep up with the times. This is coupled with a bureaucratic system that tends to corrupt. In addition, bureaucratic culture assumes that bureaucrats are entitled to be served, not just to serve the interests of society. Poor performance and pathology of bureaucracy that occurred one of them caused by the low quality of State Civil State Apparatus (ASN). The influence of KKN is still very strong in the practice of recruitment, the placement of both the mutation and promotion, so that often the human resources are not competent in the field. Therefore, this paper will answer how the mechanism of meritocracy in Indonesia. This paper is divided into 5 sections: introduction, literature review, research methods, discussion, and conclusion. 


\section{B. Literature Review-Bureaucracy}

Oftenly, we hear bureaucracy when one refers to a problem solving, a complicated and not simple problem. So not infrequently also, people use the word in the context of procedures or authority, even power. A country can be defined as a large organization, and one form of organization used by the government in its role is bureaucracy. Why is that? This begins with Max Weber's concept about bureaucracy, which considers bureaucracy as a useful tool for the implementation of rationality for administrative tasks in order to realize efficiency and effectiveness [16].

Weber [17] described bureaucracy, as in Greenwood and Lawrence's [18], Jack [19]: a fixed division of labor, a hierarchy of authority based on positions (vertical differentiation), written documents and general rules formalization), and the use of expert personnel. Another bureaucratic concept is also explained by Hegel and Marx who are later called Hegelian and Marxian [20]. The Hegelian bureaucracy emphasizes the relationship between the general power-holding group and the particular group. The relationship puts the two groups on a neutral system. The Marxian bureaucracy is the opposite. The system of relationship between the two groups of bureaucratic systems places itself in favor of the dominant group or class.

In Indonesia, its bureaucratic system is influenced by the concept of weber with the modification of Pancasila democracy [20]. The weber concept as described above has implied that to achieve bureaucratic success requires competent and professional human resources. To achieve this, the "merit system" strategy is considered an alternative force to offset the powers of political officials. Weberian bureaucracy is very thick with hierarchical system and state administration system which is also thick with the principle of power is often misused by the subject in it.

A reduced state administration system of all aspects and with a hierarchical structure design makes it sluggish. Relations between state institutions will take place harmoniously if each put themselves in the portion. However, in practice there is friction so that what happens is not mutually reinforcing but mutually fragile. Due to the political commitment of non-solid officials, this practice can be prolonged and difficult to stop. Only apolitical bureaucracy will be able to flexibly respond to all processes with a merit approach [21].

\section{Merit System}

The progress of a nation depends not only on its own natural resources, but also more determined by the ability of the nation in managing resources appropriately and well. Human resources are a major strategic factor in improving the ability to compete and survive for institutions / organizations in the era of globalization. No exception to the bureaucracy [22]. Civil servants as human resources who served to serve the public interest should have a good quality to be able to perform their duties properly and correctly. Therefore, a policy is required that can improve productivity and work performance. With application of merit system in the body of bureaucracy, it is expected to contribute to the progress of nation.

In some countries, merit system has long been implemented, for example in the USA (United States of America). States like Georgia began to implement a merit system after July 1996. It aims to acquire competent workers [23]. In Singapore, meritocracy also is a central principle of governance [24], although in the article also mentioned it gives rise to dilemma and discrimination. In Britain, the principle of merit as a recruitment and promotion was that instrumental in introducing in the nation. In some ASIA-PASIFIC countries such as Thailand, Philippine, Taiwan, Malaysia, China and South Korea have also implemented a merit system in their governance [26].

Meritocracy, as the rule of merit, may be conceived in a broad sense as a practice that rewards individual merit with social rank, job positions, higher incomes, or general recognition and prestige. The practice gives all potentially qualified and deserving individuals an equal and fair chance of achieving success on their own merit, which is usually a mixture of effort and talent, both innate and cultivated. Meritocracy, in this wider sense, points to merit as the rule or principle that governs how the economy, society, and politics are organized. In a narrower sense, the rule of merit refers simply to a political system that can select or produce the wisest and best to form a government: an "aristocracy of talent." In democratic elections, the people are given the power to decide what counts as "merit" and who possesses it [24].

Meritocracy's loosely coherent central features are themselves potentially contradictory. In their critique of the American "meritocracy myth," Stephen J. McNamee and Robert K. Miller Jr. [27] identify four types of "merit": talent, attitude, hard work, and moral character. Despite it get some critics, meritocracy continues to grow in some countries and is regarded as one way to realize a professional and competent bureaucracy. And today meritocracy in the form of open recruitment / open examination becomes important in East Asia and Southeast Asia [28]. No exception in Indonesia.

Implementation of the merit system in Indonesian bureaucracy is very important. Because merit systems for public employment are intended to ensure the integrity and effectiveness of public service by structuring the selection of procedures to ensure that employees are protected from unnecessary political interference or abuse [29]. Meanwhile, the ASN Act explains that the merit system is a policy and management for ASN that is based on qualifications, competence and performance fairly and fairly without discriminating against political background, race, color, religion, origin, gender, status marriage, age, or disability conditions. In the midst of such complex times, bureaucracy became one of the main actors in determining the future direction of a nation.

Meanwhile, according to Ambar [21], the important point of meritocracy is implementation of all policies and activities in the state institutions on central and regional levels that hold fast to the principle of professionalism. It can be done if supporting team, for example in the form institutions, officials and personnel have a necessary professionalism as apart of compliance with merit system standards. In the repertoire of human resources management called merit system is a policy, provisions, and steps that take into account 
the provisions of minimum qualifications, competency standards and performance that become the main requirements in the planning, procurement, selection, placement, compensation and employment evaluation, so it is formed professionalism which are expected.

\section{Reseacrh Method}

In writing this paper, the authors use qualitative descriptive method. Qualitative method is a research procedure that produces descriptive data in the form of writing or oral from the observed persons and holistically, then described through words and languages [30], which the data obtained is the result of the literature review. Meanwhile, some of the secondary data included is a result of documentation studies and observations [31] from various sources. Such as from previous research, organization website, regulation, news and relevant data.

\section{DISCUSSION}

Currently, change of the paradigm in organizing government bureaucracy is underway. This change has a prevalence to substitute the ways of organizing in which the centralized government to decentralized government, from authoritarian to egalitarian and democratic. Government transforms from state-oriented power into competency-oriented and increasingly concerned about the role of markets. Therefore, the implementation of merit system in Indonesian bureaucracy is expected to improve the performance and professionalism of civil apparatus. Thoha [32], Sarundajang [33] and Rozi [34] explain that consistency a merit system will encourage a healthy competitive atmosphere. At least this would be one of the prerequisites for realization of a legal and rational bureaucracy as the idea contributed by Weber [35].

Indonesian bureaucratic condition can be seen from the condition of ASN in it. Based on the observations obtained by the author are as follows:

TABLE I: NUMBERS OF ASN IN LOCAL AND NATIONAL

\begin{tabular}{|l|l|l|l|}
\hline Agency & December 2015 & December 2016 & Growth \\
\hline National & 960.795 & 918.436 & $-4,41 \%$ \\
\hline Local & 3.632 .809 & 3.455 .905 & $-4,87 \%$ \\
\hline Total & 4.593 .604 & 4.374 .341 & $-4,8 \%$ \\
\hline
\end{tabular}
Source: bkn.go.id

Based on the data (see table I), it appears that number of civil servants per December 2016 is 4,374,371 with the total population of Indonesia reached 237, 6 million [36]. The number is slightly decreased compared to 2015, which per December reached 4,593,604. Furthermore, the comparison between number of employees with the number of population can't be concluded that Indonesia has an excess number of employees. If it is presented, approximately only $2 \%$ are civil apparatus and the number which has competence is only about $40 \%$. Nearly 2 million more unproductive and incompetent employees [37].

This condition is exacerbated by ASN's competency standard which is still quite low seen from its educational qualifications. This can be seen in the following table:

\begin{tabular}{|c|c|c|c|c|c|c|}
\hline Education & Male & $\begin{array}{l}\text { Presenta } \\
\text { ge }\end{array}$ & Female & Presentage & Total & Presentage \\
\hline $\begin{array}{l}\text { Elementar } \\
\text { y School }\end{array}$ & 40.851 & $0,93 \%$ & 3.904 & $0,07 \%$ & 43.945 & $1,00 \%$ \\
\hline $\begin{array}{l}\text { Junior } \\
\text { High } \\
\text { School }\end{array}$ & 64.193 & $1,47 \%$ & 9.480 & $0,22 \%$ & 73.673 & $1,68 \%$ \\
\hline $\begin{array}{l}\text { Senior } \\
\text { High } \\
\text { School }\end{array}$ & $\begin{array}{l}648.84 \\
8\end{array}$ & $14,83 \%$ & 428.277 & $9,79 \%$ & $\begin{array}{l}1.077 .12 \\
5\end{array}$ & $24,62 \%$ \\
\hline D I & 22.064 & $0,50 \%$ & 22.930 & $0,52 \%$ & 44.994 & $1,03 \%$ \\
\hline D II & $\begin{array}{l}128.47 \\
5\end{array}$ & $2,94 \%$ & 204.836 & $4,68 \%$ & 333.311 & $7,62 \%$ \\
\hline D III & $\begin{array}{l}140.02 \\
6\end{array}$ & $3,20 \%$ & 260.825 & $5,96 \%$ & 400.851 & $9,16 \%$ \\
\hline $\begin{array}{l}\text { Bachelor/D } \\
\text { IV }\end{array}$ & $\begin{array}{l}175.35 \\
0\end{array}$ & $22,56 \%$ & $\begin{array}{l}1.114 .42 \\
2\end{array}$ & $25,48 \%$ & $\begin{array}{l}2.101 .43 \\
6\end{array}$ & $48,04 \%$ \\
\hline $\begin{array}{l}\text { Master } \\
\text { Degree }\end{array}$ & $\begin{array}{l}175.35 \\
0\end{array}$ & $4,01 \%$ & 109.154 & $2,50 \%$ & 284.504 & $6,50 \%$ \\
\hline Doctor / S3 & 10.665 & $0,24 \%$ & 3.837 & $0,09 \%$ & 14.052 & $0,33 \%$ \\
\hline Total & $\begin{array}{l}2.217 \\
486\end{array}$ & $50,69 \%$ & $\begin{array}{l}2.156 .85 \\
5\end{array}$ & $49,31 \%$ & $\begin{array}{l}4.374 .34 \\
1\end{array}$ & $100 \%$ \\
\hline
\end{tabular}

Based on the table (see table II) above, it can be concluded that almost $50 \%$ of education qualifications from ASN are still below the undergraduate level. While this may not be a benchmark for measuring ASN competencies, it is important to improve the competence of employees in order to achieve organizational goals.

The success of any organization is so strongly influenced by the wisdom of its personnel policies and the effectiveness of their administration [38]. Therefore, according to Masdar [39] the development of the quality of government apparatus resources is based on three aspects of human capital, which include: Intellectual Capital, Social Capital and Soft Capital. Where the development of the state apparatus sector contains four main missions namely: 1 realize the professional state 
organizers 2. Develop bureaucracy ethics and work culture transparent, accountable, responsiveness and realize a system of public service management that fit, precise and satisfactory. Then the government is committed to implementing system merit in bureaucratic management.

\section{A. The Constitution of ASN}

After a period of ruling new order for so long, the spirit of reform also spread within the Indonesian bureaucracy. Changes in the socio-political system and changes in the structure of an increasingly dynamic society make the bureaucracy, especially civil servants need adjustment. The implementation of merit system in Indonesian bureaucracy begins with overhauling the system of human resource development especially State Apparatus of Civil Affairs (ASN). One of them is forming a clear legal protection for the validity of the merit system in management of ASN.

The basic principles of ASN Law according to Miftah Thoha (Miftah Thoha, delivered at the time of the Organizational Theory) are:

1. Development of merit system

2. Management of human resources effectively

3. Competition in a healthy manner

4. The principle of non-discriminatotio and reducing

KKN (Corruption, Collusion, and Nepotism)

The existence of constitution number 5 of 2014 about the State Civil Apparatus [40] is part of bureaucratic reform, as stated in Presidential Regulation number 81 of 2010 [41] about the Grand Design of Bureaucratic Reform 2010-2025 which is one of the areas of change that becomes target is the apparatus resource. This condition was then considered more important than any other bureaucratic-related problem. Furthermore, the constitution of ASN purpose is:

1. Independence and neutrality

2. Competence

3. Performance / work productivity

4. Integrity

5. Prosperity

6. Quality of public services

7. Supervision and accountability

\section{B. KASN}

Far away after Indonesia's independence, the management of ASN (Civil Servant) is not well managed. The influence of $\mathrm{KKN}$ is still very strong in the practice of recruitment and placement of both mutase and promotion. So often, human resources are less competent in their field. Actually, the government has established several ministries or agencies such as Ministry of State Apparatus Empowerment and Bureaucracy Reform, LAN (State Administration Institution) and BKN (State Personnel Agency) but have not succeeded maximally.

In short, until the reform era, institutions and programs which are aimed at improving the professionalism of ASN have not been seen and tend to be on the way. Departing from global conditions and people who continue to change, Human Resource of ASN prosecuted more professional and serve. Responsiveness also needs to be improved by ASN to address increasingly complex community issues. Act number 5 of 2014 has mandated to establish a new institution in the form of a committee whose main duties and functions directly under the President. The committee is called KASN (State Civil Apparatus Committee). This institution is designated as a Merit System Protection Board [42].

The Civil State Apparatus Commission is a nonstructural institution independent of political intervention to create professional ASN employees and performs services fairly and neutrally, and becomes a glue and a unifying nation (Art. 27). In performing its duties, KASN has the following organizational structure (see Fig. 1):

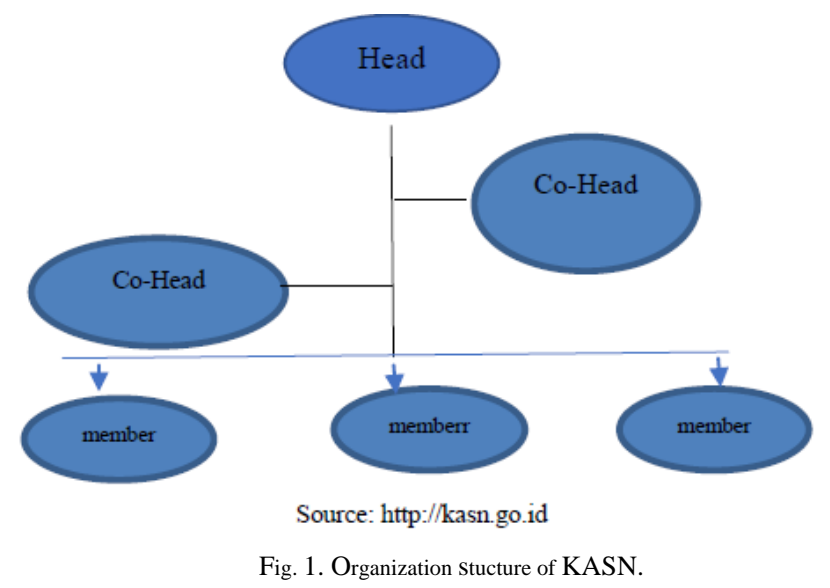

\section{Open Recruitment and Auction of Position}

In some merit system development, recruitment is considered an initial step undertaken in several countries in ASIA [26]. To obtain good officials and apparatus, system merit needs to be done with appropriate recruitment systems [21]. So the development activities and public services in a professional and responsible can be held by the government. According to Flynn and Strehl [43]: Recruitment to the public service is essentially by open competitive examinations. This is considered to produce equality of acces and recruitment on merit.

In 2017, Government through the Ministry of State Apparatus Empowerment and Bureaucracy Reform opens an open recruitment of ASN in 61 ministries / Institutions and Local Government with details of 30 ministries, 30 institutions and one Local Government totaling 17,928 positions. The recruitment has implemented computer-based selection called CAT (Computer Assessment Test). The implementation of CAT itself has actually been done during the recruitment period of 2014. In the ASN recruitment process, it is divided into three stages covering administrative selection, selection of basic competencies and the selection of field competencies (Article 62). This innovation aims to provide a fast, accountable and transparent recruitment system. Through this kind of mechanism, KKN practices can be reduced. In addition, with a strict and fair recruitment is expected to capture the best talent to be civil servant in this country.

After merit system through the recruitment mechanism, then another step in personnel management is the auction of positions. Auction of position is an open selection conducted by an organization to fill a certain position in accordance with the capacity and competence possessed in order to achieve effectiveness and efficiency. In the concept of New Public Management official auction is commonly done in western 
countries with different terms such as auction fee [44]. In Indonesia office auctions are usually enforced at the echelon 2 and 3 levels. In some areas an auction has been held. Such as in Surabaya city and DKI Jakarta. The existence of the auction of position is intended to obtain a competent ASN and professional. Besides, with the open office auction is to reduce nepotism and compromise in the government bureaucracy system

\section{E-performance}

Performance in task implementation is always followed by evaluation. In this case, it concerns organizational performance and individual performance. Individual performance according to Sudarmanto [45] is an achievement or effectiveness at employee and job level. Meanwhile, according to Flynn [46] performance measurement in public management includes efficiency at the first level includes inputs, processes or production and capacity functions, while efficiency at level two includes inputs, processes or production functions, capacities, output channels and outputs itself. In this case, public organizations are identified with output in the form of public services.

The performance of ASN which has been considered less productive and less disciplined tends to be needed to increase its productivity. One way is to use the e-performance system. E-performance is a performance measurement system activity / work unit of regional devices electronically based online / website. Through e-performance we know how effective the performance of an apparatus. The results of this e-performance will then affect the salary system and opportunities for promotion or promotion. So, it is expected with e-performance, apparatus able to improve work discipline [47], performance and productivity.

E-performance in Indonesia has been implemented in the Ministry and several local governments such as Surabaya, Bandung, Jakarta and several other areas. Although only applied in big cities in Indonesia, these does not close the hope will spread throughout Indonesia in the future. This is part of the government's commitment to support e-government efforts as a means of transparency and accountability to the community. In addition, e-performance becomes the basis in providing a fair salary according to the competence and performance.

\section{CONCLUSION}

The comprehensive implementation of merit system in Indonesian bureaucracy is an urgent need. It needs to be implemented as a bureaucratic transformation to face the challenges and developments of global society. The competence and professionalism of ASN are expected to increase productivity and public service. To get professional human resources of bureaucracy, one of the efforts is the application of merit system. Clear and compatible platform will strengthen merit in this system and also the implementation of open and competitive bureaucratic apparatus management in Indonesia. This will be even better if it is supported by an HR management process that really follows the recruitment pattern until a clear, descriptive and fair evaluation.
However, Indonesia meritocracy is still running halfway and not yet optimal. This implementation of merit system has similarity in some Asian countries, which is only interpreted through open selection (examinations). The constraints in Indonesia are also similar, that is filling position and promotion still not fully apply a merit system. Like and dislike to be something we encounter in Indonesian bureaucracy. Unlike the Weberian bureaucracy that regulates impersonal relationships, it appears that the civil servant process in Indonesia has many personal practices and uses proximity relationships. Therefore, further research that could be the focus is how the merit system is applied in the process of career apparatus in Indonesia.

\section{ACKNOWLEDGMENT}

The Authors would like to thanks for Indonesia Endowment Fund for Education, which has supported and financed us. And we also would like to thanks for Universitas Gadjah Mada has given us an opportunity.

\section{REFERENCES}

[1] M. Jeddawi, R. Birokrasi, and Kelembagaan, "Pembinaan PNS," Yogyakarta: Kreasi Total Media, p. 13, 2008.

[2] J. M. D. Rahmat, "Peran birokrasi pemerintah sebagai penyelenggara pelayanan public," Article, Law Dept, Universitas of Asahan, Kisaran, Sumatera Utara, 2017.

[3] M. Thoha and B. D. D. Kekuasan, Jakarta: Pranadamedia, p. 1, 2014.

[4] M. Weber, "The theory of economic and social organization," New York, NY: Oxford University Press, p. 336, 1947.

[5] R. Greenwood and T. B. Lawrence, "The iron cage in the information age: The legacy and relevance of max weber for organization studies," Ed. Organization Studies, vol. 26, no. 4, pp. 493-499, 2005.

[6] J. Lumby, "Distributed leadership and bureaucracy," Educational Management Administration \& Leadership. pp. 1-15, 2017.

[7] M. Tjokrowinoto, "Politik pembangunan: Sebuah arah, konsep dan strategi," Yogyakarta: Tiara Wacana, p. 82, 1987.

[8] E. Sofian, "Debirokratisasi dan deregulasi: Upaya meningkatkan kemampuan administrasi untuk melaksanakan pembangunan. Yogyakarta," UGM Monograph, p. 3, 1987.

[9] A. Dwiyanto, "Mengembalikan kepercayaan publik melalui reformasi birokrasi," Jakarta: Gramedia Pustaka Utama, pp. 154-160, 2011.

[10] B. Hajar, "Bureaucracy and governance in Indonesia: Study on west sulawesi province," Procedia Economics and Finance, Czech Republic, pp. 223-227, 2015.

[11] A. Black, "The victorian information society: Surveillance, bureaucracy, and public librarianship in 19th-Century Britain," An International Journal, vol. 17, pp. 63-80, 2001.

[12] W. James, "A processual view of institutional change of the budget processwithin an Australian government-owned electricity corporation," International Journal of Public Sector Management, vol. 19, no. 1, pp. 5-39, 2006.

[13] J. Q. Wilson, "The bureaucracy problem: The public interest," USA: Basic Book, pp. 3-9, 1967.

[14] R. H. McLeod, "The struggle to regain effective governance under democracy in Indonesia," Bulletin of Indonesian Economic Studdies, vol. 41, no. 3, pp. 367-386, 2005.

[15] J. Q. Wilson, The Politic of Regulation, pp. 357-394, 1980,

[16] G. Pramuka. (March 1987). Masalah Birokrasi sebagai Pelayanan Publik. Jurusan Ilmu Administrasi Negara FISIP, Universitas Airlangga. [Online]. Available: http://journal.unair.ac.id

[17] M. Weber, "The theory of economic and social organization new york," NY: Oxford University Press, p. 336, 1947.

[18] R. Greenwood and T. B. Lawrence, "The iron cage in the information age: The legacy and relevance of Max Weber for organization studies," Editorial. Organization Studies, vol. 26, no. 4, pp. 493-499, 2005.

[19] J. Lumby. (2017). Distributed leadership and bureaucracy. Educational Management Administration \& Leadership. [Online]. 2. pp 1-15. Available: www.journals.sagepub.com/home/ema

[20] M. Thoha, "Birokrasi dan Dinamika Kekuasaan," Jakarta: Prenadamedia, pp. 3-8, 2014. 
[21] A. T. Sulistiyani, "Meritokrasi dalam sistem administrasi negara indonesia, in reformasi aparatur negara ditinjau kembali, wahyudi kumorotomo and ambar widaningrum," Yogyakarta: Gava Media, pp. 84-96, 2010.

[22] A. Daryanto, "Merit system dalam manajemen pegawai negeri sipil", Pusat Pengkajian dan Penelitian Kepegawaian BKN (Badan Kepegawaian Negara)," Jurnal Kebijakan dan Manajemen PNS, October 2007.

[23] L. G. Nigro and J. E. Kellough, "Civil service reform in Georgia: A view from the trenches, in civil service reform in the states: Personnel policy and politics at the subnational level," Albany: State University of New York Press, pp. 117-144, 2006.

[24] K. P. Tan, "Meritocracy and elitism in a global city: ideological shifts in singapore," International Political Science Review, Sage publications, vol. 29, no. 1, pp. 7-27, 2008.

[25] S. Northcote and C. Trevelyan, "Report on the organization of the permanent civil service," Parliamentary Paper 1713, 1854.

[26] O. O. Poocharoen and A. Brillante, (2013). Meritocracy in asia pacific: status, issues, and challenges. Review of Public Personnel Administration [Online]. 33(2). pp. 140-163. Available: http://sagepub.com/journalsPermission.nav

[27] McNamee, J. Stephen, Miller, and K. Robert Jr, "Meritocracy myth. Lanham," MD: Rowman and Littlefield, 2004.

[28] E. Berman, "Public administration in East Asia: Mainland China, South Korea, Japan," Taiwan. Boca Raton, FL: CRC Press, p. 5, 2010.

[29] Administrative values and public personnel management: reflections on civil service reform. Public Personnel Management. [Online]. 45(2) pp. 171-189.

Available: http://sagepub.com/journalsPermission.nav

[30] L. J. Moleong, "Metodologi penelitian kualitatif, bandung: Remaja rosdakarya," pp. 4-6, 2004.

[31] S. L. D. R. Hegedorn, "Metode riset sosial: Suatu pengantar," Jakarta: Erlangga, p. 68, 1982.

[32] Sarundajang, "Babak baru sistem pemerintahan daerah," Jakarta: Kata Hasta, 2005.

[33] M. Thoha, "Birokrasi pemerintahan daerah Indonesia di Era reformasi," Jakarta: Kencana, p. 308, 2008.

[34] S. Rozi, "Zaman bergerak, birokrasi dirombak: Potret birokrasi dan politik di Indonesia," Yogyakarta:P2P LIPI dan Pustaka Pelajar, p. 15, 2006.

[35] Edison. (May 2011). Meritokrasi vs politisasi jabatan karir dalam birokrasi lokal: sebuah paradoks netralitas birokrasi. Jurnal Kebijakan dan Administrasi Publik [Online]. 16(1). pp. 67-76. Available: https://journal.ugm.ac.id/jkap

[36] J. Penduduk. (2016). [Online]. Available: www.bps.go.id
[37] M. Thoha, "Manajemen kepegawaian sipil di Indonesia," Jakarta: Pranadamedia (Kencana), pp. 23, 2014.

[38] O. W. Wilson, "Toward a Better Merit System," University of California, Sage Publications Inc.

[39] Birokrasi dan Pelayanan Publik, "Irfan Sangadji," FISIP UI, 2010.

[40] “Ang-undang tahun tentang," Aparatur Sipil Negara, no. 5, 2014

[41] Perpres nomor 81 tahun 2010 tentang Grand Design Reformasi Birokrasi.

[42] "Miftah thoha, manajemen kepegawaian sipil di Indonesia," Oktober Jakarta: Pranadamedia (kencana) hal 272, 2014.

[43] N. Flynn and F. Strehl, "Englewood cliffs: Prentice hall, harvester wheatsheaf," Public Sector Management in Europe, pp. 116, 1996.

[44] M. Asnawi, "Lelang Jabatan dalam tinjauan good governance (studi kasus pemerintahan kota makassar tahun 2014," Scription, Dept. Political Science, Universitas Alauddin Makassaar, 2016.

[45] Sudarmanto and K. D. P. Kompetensi, SDM, Yogyakarta: Pustaka Pelajar, p. 8, 2009.

[46] N. Flynn, "New York, London, Toronto, Sydney, Tokyo: Harvester wheatsheaf," Public Sector Management, 2nd edition, p. 112, 1993.

[47] S, A. D. E. H. Fanida. (2014). Pengaruh e-performance terhadap tingkat kedisiplinan pegawai negeri sipil (studi kasus dinas pendidikan kota surbaya). Unesa Surabaya. [Online]. Available: http://ejournal.unesa.ac.id/article/1786/42/article.pdf

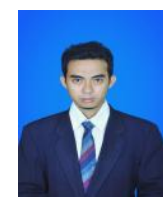

Fauzul Mubin was born Ogyakarta, in 1986. Fauzul was a student of English Department at Universitas Gadjah Mada started from 2004 until graduated his program at early 2009 In 2012 he became a Civil Servant at The Ministry of Law and Human Right. And then, in 2016 he got a scholarship from LPDP. Early 2017, he started his postgraduate program of Public Administration at Universitas Gadjah Mada.

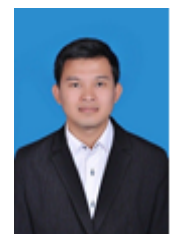

Ali Roziqin was born in Rembang, in 1994. Ali was as student of Public Administration Departement at Diponegoro University from 2012-2016, and now Ali is a student of magister of public administration at Universitas Gadjah Mada with scholarship from LPDP (Indonesia Endowment for Education). 